\title{
CD3 Negative
}

National Cancer Institute

\section{Source}

National Cancer Institute. CD3 Negative. NCI Thesaurus. Code C142095.

An indication that expression of $\mathrm{CD} 3$ has not been detected in a sample. 